\title{
Coagulation fibrinolysis in sickle-cell disease
}

\author{
P. A. GORDON, G. R. BREEZE, J. R. MANN, AND J. STUART
}

From the Department of Haematology, The Children's Hospital, Birmingham

SYNOPSIS A study of fibrinolytic activity in sickle-cell patients during asymptomatic periods has shown a normal fibrinolytic response to exercise and local heat to the arm. During vasoocclusive crises there was no significant decrease in fibrinolytic activity. These results contrast with earlier reports of decreased fibrinolysis during crisis and a suggestion that fibrinolytic activators might be of value in preventing vasoocclusive episodes.

Patients in painful crisis showed a significant rise in fibrinogen concentration and fall in platelet count. The former may contribute to localized vascular sludging by increasing whole-blood viscosity, while the latter probably results from local trapping of platelets in areas of sickling or from subsequent splenic sequestration of damaged platelets. There was no evidence of disseminated, as opposed to localized, intravascular coagulation during crisis.

The painful vasoocclusive crisis of sickle-cell anaemia results primarily from sickling and sludging of red cells. The resulting vascular stasis, red cell damage, and endothelial cell hypoxia may then result in secondary fibrin deposition (Walters, 1958; Diggs, 1965; Diggs, 1973) which could contribute to vascular obstruction and delay clinical recovery. Anticoagulants have therefore been advocated for the prevention and treatment of crises (Murphy and Shapiro, 1945; Salvaggio, Arnold, and Banov, 1963; Gilles, Reid, Odutola, Ransome-Kuti, Lesi, and Ransome-Kuti, 1968).

A more extensive degree of fibrin deposition, disseminated intravascular coagulation, has also been described as a complication of vasoocclusive crisis in sickle-cell anaemia (Hardaway, 1966) and the trait (Jones, Binder, and Donowho, 1970), and as a complication of marrow infarction and fat embolism (Hutchinson, Merrick, and White, 1973). Disseminated intravascular coagulation may possibly be involved to a variable extent in acute crises (Nalbandian, 1973).

A decrease in fibrinolytic activity during sicklecell crisis would exacerbate any tendency to fibrin deposition. Mahmood, Macintosh, and Shaper (1967) and Mahmood (1969) reported a decrease in fibrinolysis, as measured by the whole-blood lysis time, during crisis and suggested the use of fibrinolytic activators for prophylaxis. Green, Kwaan, and Ruiz (1970) and Walsh, Lusher, and Barnhart (1973) have also reported decreased fibrinolytic activity in sickle-cell anaemia although Green et al (1970)

Received for publication 19 March 1974. found that this decrease correlated with infection rather than with the vasoocclusive crisis. In contrast, Hilgartner, Horowitz, Erlandson, Ferguson, and Smith (1961) reported increased fibrinolytic activity during crisis.

The present study was therefore designed to investigate coagulation-fibrinolytic activity in sicklecell disease in relation to painful crises and the presence of infection.

\section{Patients and Methods}

A total of 38 children aged 2-16 years were studied: 23 of them had homozygous sickle-cell disease, six had sickle-cell-haemoglobin $C$ disease, three had sickle-cell-thalassaemia, and six in whom family studies could not be completed had either sickle-cell disease or sickle-cell thalassaemia. Studies were carried out during admission for a total of 35 painful crises, with and without associated infection, and during asymptomatic periods when the patients attended a follow-up haematology clinic. The infections consisted of either pneumonia or acute follicular tonsillitis. Informed parental consent was obtained for the tests involving exercise and local heat to the arm.

\section{Methods}

Venous blood samples obtained using minimal venous occlusion were immediately chilled on melting ice before centrifugation at $0-4^{\circ} \mathrm{C}$. Plasma for factor V, factor VIII, fibrinogen, and plasmino- 
gen assays was stored at $-20^{\circ} \mathrm{C}$ and subsequently assayed in batches together with control specimens. The majority of venepunctures were performed between 10.00 and 11.00 a.m. to standardize the effect of the diurnal fibrinolytic rhythm (Fearnley, Balmforth, and Fearnley, 1957). Packed cell volume (PCV) was measured by a microhaematocrit method and platelet counts were performed by direct visual counting (Dacie and Lewis, 1968). Factors V and VIII were assayed by one-stage assays (Biggs and Macfarlane, 1966; Hardisty and Ingram, 1965). Fibrinogen was measured by the method of Ratnoff and Menzie (1951) as modified by Alkjaersig (1960). Plasminogen was assayed by the caseinolytic method of Remmert and Cohen (1949), as modified by Alkjaersig, Fletcher, and Sherry (1959). Euglobulin lysis time (ELT) was estimated by the method of Cash and Allan (1967). Serum fibrin degradation products (FDP) were assayed by the method of Merskey, Kleiner, and Johnson (1966) as modified by Das, Allan, Woodfield, and Cash (1967) and using fibrinogen-sensitized sheep red blood cells (Wellcome Research Laboratories). Plasminogen activator was measured on human fibrin plates prepared according to Astrup and Müllertz (1952), as modified by Cash and Allan (1967), and free plasmin was estimated on fibrin plates (as before) preheated at $80^{\circ} \mathrm{C}$ for 30 minutes. The dilute wholeblood lysis time (WBLT) was measured by the method of Fearnley (1964).

A standardized submaximal step-up exercise of 75 seconds' duration was used to study the effect of exercise on the fibrinolytic activity of fit, asymptomatic patients (Cash, 1966). The patients were kept at rest for 30 minutes before the pre-exercise venepucture. The effect of local heat was studied by placing one arm in a water bath at $45^{\circ} \mathrm{C}$ for 10 minutes (Dodman, Cunliffe, Roberts, and Buchan, 1973), and blood was sampled from this arm immediately before and after the procedure.
Statistical significance values were calculated using Student's t test and the paired-t test.

\section{Results}

The results obtained for the four patient groups(1) asymptomatic patients, (2) infected patients not in painful crisis, (3) painful crisis without infection, (4) painful crisis with infection-are given in tables I and II.

The effect of infection on patients who were not in crisis was studied by comparing groups 1 and 2 . 용 The only significant abnormality (see table I) was in a slight rise in mean serum FDP level in the infected patients. There was no significant difference between infected and uninfected patients during sickle-cell ${ }^{\infty}$ crisis (group 3 vs group 4) for any of the tests (see 옥 table II).

The effect of painful crisis, ignoring the presence $\bar{c}$ of infection, is shown in table III (groups 1 plus $2 \underset{\mathbb{D}}{\overrightarrow{0}}$ vs 3 plus 4). There was a significant fall in the mean $\vec{\varphi}$ platelet count $(\mathrm{P}<0.05)$ and a significant rise in the mean fibrinogen level $(\mathrm{P}<0.02)$ during crisis. The euglobulin lysis time in crisis was slightly prolonged but this was not statistically significant $(\mathrm{P}>0 \cdot 1)$.

All results obtained for the plasma activity of plasminogen activator and free plasmin, as determined by the fibrin plate method, were within the $\overrightarrow{\vec{O}}$ normal range with no increase in the area of lysis 3 and are not given in detail.

The effect of submaximal exercise and of local heat to the arm are given in table IV. The euglobulin lysis time was shortened after exercise in six out of seven patients and the whole blood lysis time was shortened in eight out of nine. After local heat to the arm, the euglobulin lysis time was shortened in six out of six patients and the whole blood lysis time in four out of four.

\begin{tabular}{|c|c|c|c|c|c|c|c|c|}
\hline & $P C V$ & $\begin{array}{l}\text { Platelets } \\
\left(\times 10^{\circ} / 1\right)\end{array}$ & $\begin{array}{l}\text { Factor } V \\
(\%)\end{array}$ & $\begin{array}{l}\text { Factor VIII } \\
(\%)\end{array}$ & $\begin{array}{l}\text { Fibrinogen } \\
(g / l)\end{array}$ & $\begin{array}{l}\text { Plasminogen } \\
\text { (casein } \\
\text { units } / \mathrm{ml} \text { ) }\end{array}$ & $\begin{array}{l}F D P \\
(\mu g / m l)\end{array}$ & $\begin{array}{l}E L T \\
(\min )\end{array}$ \\
\hline $\begin{array}{l}\text { Group } \\
\text { Mean } \\
\pm \text { SD } \\
\text { Range }\end{array}$ & $\begin{array}{l}\text { Infected) } \\
0.26 \\
0.04 \\
0.18-0.37 \\
(40)^{1}\end{array}$ & $\begin{array}{l}360 \\
237 \\
120-1180 \\
(29)\end{array}$ & $\begin{array}{c}134 \cdot 5 \\
40 \cdot 6 \\
74-200 \\
(15)\end{array}$ & $\begin{array}{l}193 \cdot 2 \\
88 \cdot 3 \\
86-380 \\
(16)\end{array}$ & $\begin{array}{l}2 \cdot 02 \\
0 \cdot 55 \\
1 \cdot 2-3 \cdot 85 \\
(37)\end{array}$ & $\begin{array}{l}2 \cdot 35 \\
0 \cdot 56 \\
0 \cdot 85-3 \cdot 5 \\
(40)\end{array}$ & $\begin{array}{l}8 \cdot 6 \\
5 \cdot 6 \\
2-32 \\
(38)\end{array}$ & $\begin{array}{l}198 \cdot 7 \\
123 \cdot 6 \\
60-600 \\
(20)\end{array}$ \\
\hline $\begin{array}{l}\text { Group } \\
\text { Mean } \\
\pm \text { SD } \\
\text { Range }\end{array}$ & $\begin{array}{l}\text { (ected) } \\
\quad 0.22 \\
0.04 \\
0 \cdot 17-0.28 \\
(5)\end{array}$ & $\begin{array}{l}286 \\
122 \\
115-496 \\
(5)\end{array}$ & $\begin{array}{l}95 \cdot 9 \\
45 \cdot 8 \\
42-180 \\
(9)\end{array}$ & $\begin{array}{l}155 \cdot 1 \\
84 \cdot 2 \\
66-340 \\
(7)\end{array}$ & $\begin{array}{l}2 \cdot 57 \\
3 \cdot 92 \\
1 \cdot 5-3 \cdot 45 \\
(9)\end{array}$ & $\begin{array}{l}2 \cdot 48 \\
0 \cdot 64 \\
1 \cdot 1-3 \cdot 1 \\
(9)\end{array}$ & $\begin{array}{l}17 \cdot 5 \\
9 \cdot 3 \\
5-28 \\
(9)\end{array}$ & $\begin{array}{l}364 \cdot 4 \\
276 \cdot 6 \\
100-1080 \\
(9)\end{array}$ \\
\hline $\mathbf{P}$ & $>0.1$ & $>0.1$ & $>0.05$ & $>0.1$ & $>0.1$ & $>0.1$ & $<0.02$ & $>0.1$ \\
\hline
\end{tabular}

Table I Effect of infection on patients when not in crisis

${ }^{2}$ Number of patients studied in parentheses 


\begin{tabular}{|c|c|c|c|c|c|c|c|c|}
\hline & $P C V$ & $\begin{array}{l}\text { Platelets } \\
\left(\times 10^{\circ} / l\right)\end{array}$ & $\begin{array}{l}\text { Factor } V \\
(\%)\end{array}$ & $\begin{array}{l}\text { Factor VIII } \\
(\%)\end{array}$ & $\begin{array}{l}\text { Fibrinogen } \\
(\mathrm{g} / \mathrm{l})\end{array}$ & $\begin{array}{l}\text { Plasminogen } \\
\text { (casein } \\
\text { units/ml) }\end{array}$ & $\begin{array}{l}F D P \\
(\mu g / m l)\end{array}$ & $\begin{array}{l}E L T \\
(\min )\end{array}$ \\
\hline $\begin{array}{l}\text { Group } 3 \\
\text { Mean } \\
\pm \text { SD } \\
\text { Range }\end{array}$ & $\begin{array}{l}\text { Infected) } \\
0.27 \\
0.04 \\
0 \cdot 16-0 \cdot 34 \\
(20)^{1}\end{array}$ & $\begin{array}{l}266 \\
94 \\
135-375 \\
(18)\end{array}$ & $\begin{array}{l}76 \cdot 2 \\
13 \cdot 4 \\
62-100 \\
(5)\end{array}$ & $\begin{array}{l}104 \\
10 \cdot 2 \\
90-120 \\
(5)\end{array}$ & $\begin{array}{l}2 \cdot 73 \\
0 \cdot 58 \\
1 \cdot 85-3 \cdot 5 \\
(17)\end{array}$ & $\begin{array}{l}2 \cdot 5 \\
0 \cdot 54 \\
1 \cdot 2-3 \cdot 2 \\
(20)\end{array}$ & $\begin{array}{c}13 \cdot 0 \\
9 \cdot 1 \\
3-32 \\
(21)\end{array}$ & $\begin{array}{l}357 \\
77 \cdot 3 \\
270-450 \\
(5)\end{array}$ \\
\hline $\begin{array}{l}\text { Group } 4 \\
\text { Mean } \\
\pm \text { SD } \\
\text { Range }\end{array}$ & $\begin{array}{l}\text { cted) } \\
0 \cdot 26 \\
0.04 \\
0 \cdot 17-0.33 \\
(15)\end{array}$ & $\begin{array}{l}253 \\
80 \cdot 9 \\
125-500 \\
(14)\end{array}$ & $\begin{array}{l}119 \\
71 \cdot 0 \\
48-190 \\
(2)\end{array}$ & $\begin{array}{l}295 \\
85 \cdot 0 \\
210-380 \\
(2)\end{array}$ & $\begin{array}{l}3 \cdot 02 \\
0 \cdot 56 \\
2 \cdot 0-3 \cdot 5 \\
(10)\end{array}$ & $\begin{array}{l}2 \cdot 3 \\
0 \cdot 75 \\
0 \cdot 6-3 \cdot 1 \\
(12)\end{array}$ & $\begin{array}{l}21 \cdot 4 \\
31 \cdot 2 \\
3 \cdot 5-128 \\
(12)\end{array}$ & $\begin{array}{l}282 \\
122 \\
165-480 \\
(5)\end{array}$ \\
\hline $\mathbf{P}$ & $>0.5$ & $>0.5$ & $>0.5$ & $>0.05$ & $>0.1$ & $>0.5$ & $>0.1$ & $>0.1$ \\
\hline
\end{tabular}

Table II Effect of infection on patients in crisis

${ }^{1}$ Number of patients studied in parentheses.

\begin{tabular}{|c|c|c|c|c|c|c|c|c|}
\hline & $P C V$ & $\begin{array}{l}\text { Platelets } \\
\left(\times 10^{\circ} / \mathrm{l}\right)\end{array}$ & $\begin{array}{l}\text { Factor } V \\
(\%)\end{array}$ & $\begin{array}{l}\text { Factor VIII } \\
(\%)\end{array}$ & $\begin{array}{l}\text { Fibrinogen } \\
(\mathrm{g} / \mathrm{l})\end{array}$ & $\begin{array}{l}\text { Plasminogen } \\
\text { (casein } \\
\text { units/ml) }\end{array}$ & $\begin{array}{l}F D P \\
(\mu g / m l)\end{array}$ & $\begin{array}{l}E L T \\
(\min )\end{array}$ \\
\hline $\begin{array}{l}\text { Groups } \\
\text { Mean } \\
\text { ISD } \\
\text { Range }\end{array}$ & $\begin{array}{l}2 \text { (Not in Cri } \\
0.25 \\
0.04 \\
0 \cdot 17-0.38 \\
(45)^{1}\end{array}$ & $\begin{array}{l}349 \\
225 \\
115-1180 \\
(34)\end{array}$ & $\begin{array}{l}120 \\
46 \cdot 6 \\
42-200 \\
(24)\end{array}$ & $\begin{array}{l}181 \cdot 6 \\
88 \cdot 8 \\
66-380 \\
(23)\end{array}$ & $\begin{array}{l}2 \cdot 12 \\
0 \cdot 60 \\
1 \cdot 2-3 \cdot 85 \\
(46)\end{array}$ & $\begin{array}{l}2 \cdot 37 \\
0.58 \\
0.85-3.5 \\
(49)\end{array}$ & $\begin{array}{c}10 \cdot 3 \\
7 \cdot 37 \\
2-32 \\
(47)\end{array}$ & $\begin{array}{l}250 \cdot 1 \\
200 \cdot 4 \\
60-1080 \\
(29)\end{array}$ \\
\hline $\begin{array}{l}\text { Groups } \\
\text { Mean } \\
\pm \text { SD } \\
\text { Range }\end{array}$ & $\begin{array}{l}4 \text { (In Crisis) } \\
0 \cdot 26 \\
0.04 \\
0 \cdot 16-0.34 \\
(35)\end{array}$ & $\begin{array}{l}260 \\
88 \cdot 8 \\
125-500 \\
(32)\end{array}$ & $\begin{array}{l}88 \cdot 4 \\
44 \cdot 0 \\
48-190 \\
(7)\end{array}$ & $\begin{array}{l}158 \cdot 6 \\
97 \cdot 9 \\
90-380 \\
(7)\end{array}$ & $\begin{array}{l}2 \cdot 84 \\
1 \cdot 40 \\
1 \cdot 85-3 \cdot 5 \\
(27)\end{array}$ & $\begin{array}{l}2 \cdot 42 \\
0 \cdot 64 \\
0 \cdot 6-3 \cdot 2 \\
(32)\end{array}$ & $\begin{array}{l}16 \cdot 05 \\
21 \cdot 4 \\
3 \cdot 0-128 \\
(33)\end{array}$ & $\begin{array}{l}319 \cdot 5 \\
108 \cdot 8 \\
165-480 \\
(10)\end{array}$ \\
\hline $\mathbf{P}$ & $>0.5$ & $<0.05$ & $>0.1$ & $>0.5$ & $<0.02$ & $>0.5$ & $>0.1$ & $>0.1$ \\
\hline
\end{tabular}

Table III Effect of crisis ignoring the presence of infection

${ }^{1}$ Number of patients studied in parentheses.

\begin{tabular}{|c|c|c|c|c|c|c|c|}
\hline \multicolumn{4}{|c|}{ Effect of Exercise } & \multicolumn{4}{|c|}{ Effect of Local Heat } \\
\hline \multicolumn{2}{|c|}{$E L T(\min )$} & \multicolumn{2}{|c|}{$W B L T(\min )$} & \multicolumn{2}{|c|}{$E L T(m i n)$} & \multicolumn{2}{|c|}{$W B L T(\min )$} \\
\hline Before & After & Before & After & Before & After & Before & After \\
\hline $\begin{array}{l}280 \\
120 \\
270 \\
240 \\
240 \\
180 \\
180 \\
-\end{array}$ & $\begin{array}{r}160 \\
80 \\
270 \\
210 \\
210 \\
150 \\
150 \\
=\end{array}$ & $\begin{array}{r}330 \\
480 \\
1440 \\
600 \\
300 \\
390 \\
270 \\
1080 \\
600\end{array}$ & $\begin{array}{l}285 \\
180 \\
360 \\
540 \\
240 \\
240 \\
300 \\
800 \\
340\end{array}$ & $\begin{array}{r}90 \\
240 \\
165 \\
90 \\
110 \\
60\end{array}$ & $\begin{array}{r}75 \\
180 \\
135 \\
70 \\
100 \\
50\end{array}$ & $\begin{array}{l}360 \\
960 \\
840 \\
420 \\
- \\
-\end{array}$ & $\begin{array}{l}300 \\
720 \\
720 \\
240 \\
- \\
-\end{array}$ \\
\hline $\mathbf{P}^{1}$ & & & & & & & \\
\hline
\end{tabular}

Table IV Effect of exercise and of local heat to the arm on the euglobulin and whole-blood lysis times

${ }^{2}$ Statistical significance determined by the paired-t test.

\section{Discussion}

The results of this study failed to show any statistically significant impairment of fibrinolytic activity in sickle-cell patients either when asymptomatic or during painful crisis. The euglobulin lysis time was prolonged during crisis and in patients with infection but this prolongation did not reach statistical significance and was possibly due to the associated increase in fibrinogen concentration. The investigations on asymptomatic sickle-cell patients showed a normal fibrinolytic response to submaximal exercise, even though the step-up procedure was deliberately restricted to 75 seconds because of the 
patients' anaemia. The fibrinolytic response to local heat, as measured by the euglobulin and whole blood lysis times, was again normal.

A previous fibrinolytic study during ancrod therapy for sickle-cell crisis (Mann, Breeze, Deeble, and Stuart, 1972) also showed that sickle-cell patients can achieve an apparently normal release of plasminogen activator in response to the intravascular fibrin microclot formation induced by ancrod.

A serial study of coagulation-fibrinolytic activity in individual patients during asymptomatic periods and in crisis is likely to reveal considerable fluctuations in coagulation factor levels and fibrinolytic activity. This would be an expected response in a disease with periodic episodes of infection, dehydration, localized vascular occlusion, liver cell hypoxia, and splenic infarction. The results of the present study indicate, however, that sickle-cell patients do not have a basic impairment of their fibrinolytic system and suggest that fibrinolytic enzyme activation is unlikely to be of clinical value for either prophylaxis or treatment.

During crisis, the mean fibrinogen level rose significantly. The reason for this is unclear but it was not related to infection or to alteration in packed cell volume. Plasma fibrinogen has been shown to be a critical determinant of the flow properties of red cell suspensions (Wells, Grawronski, Cox, and Perera, 1964), causing increased whole-blood viscosity by fibrinogen-red cell interaction (Replogle, Meiselman, and Merrill, 1967). This effect is increasingly pronounced at low shear rates (Weaver, Evans, and Walder, 1969) as in the microvasculature in sickle-cell crisis. This raised fibrinogen concentration may possibly contribute to red cell sludging during crisis. When the crisis has become established, however, then removal of the fibrinogen by therapeutic defibrination with ancrod (Mann et al, 1972; Haddock, Bonotey-Ahulu, Janosi, Ankra-Badu, and Reid, 1973) does not hasten clinical recovery.

Previous studies (Green and Ruiz, 1968; Green et al, 1970; Walsh, Lusher, and Barnhart, 1973) have shown significantly raised platelet counts in patients with sickle-cell anaemia compared with normal control subjects. This increase has been described during asymptomatic periods, during crisis, and during crisis plus infection. Platelet survival studies in adult sickle-cell patients have shown significantly prolonged survival during asymptomatic periods compared with that in healthy controls (Haut, Cowan, and Harris, 1973). In contrast, the present study in children (mean age 7.6 years) has not shown a significant increase $(P>0.05)$ in the mean platelet count during asymptomatic periods compared with the mean value for hospital control patients admitted for elective surgical procedures (Ihenacho, Breeze, Fletcher, and Stuart, 1973). The older adolescent and the adult patient with sickle-cell anaemia has usually undergone splenic atrophy due to recurrent microinfarction (Diggs, 1963); the thrombocytosis of older patients may therefore be a consequence of autosplenectomy in contrast with the presumed better splenic function and normal platelet counts of our younger patients.

In painful crisis, however, our patients showed a small but significant $(P<0.05)$ fall in the mean platelet count. Platelet kinetic studies in adult patients (Haut et al, 1973) have also shown that platelet survival falls to one-third of normal during painful crisis. These results could be explained on the basis of mild disseminated intravascular coagulation triggered by thromboplastin release from damaged, sickled erythrocytes. Although disseminated intravascular coagulation may occur as a rare complication in a severely hypoxic, acidotic patient, it would not seem to be the correct explanation for the platelet fall in our less severely ill patients since the fibrinogen level rose significantly and there was no significant fall in either factor V, factor VIII, or plasminogen, or significant rise in serum FDP The modest fall in platelet count could be explained by trapping and consumption of platelets in localized areas of red cell sickling and fibrin deposition. Alternatively, platelet damage could occur in these areas with subsequent removal of the damaged platelets by reticuloendothelial cell activity in a functioning spleen.

We are indebted to the United Birmingham Hospitals Endowment Research Fund for financial support, to the paediatricians of The Children's Hospital for allowing us to study their patients, and to $\mathrm{Mr} \mathrm{D}$. J. Fletcher for technical assistance. Reprint requests to J.S.

\section{References}

Alkjaersig, N. (1960). In Proceedings of the Conference on Thrombolytic Agents, edited by H. R. Roberts and J. D. Geraty, p. 136. Chicago.

Alkjaersig, N., Fletcher, A. P., and Sherry, S. (1959). The mechanism N of clot dissolution by plasmin. J. clin. Invest., 38, 1086-1095.

Astrup, T., and Müllertz, S. (1952). The fibrin plate method for $\mathrm{W}$ estimating fibrinolytic activity. Arch. Biochem., 40, 346-351.

Biggs, R., and Macfarlane, R. G. (1966). Treatment of Haemophilia and $<$ Other Coagulation Diseases, pp. 368-369. Blackwell, Oxford.

Cash, J. D. (1966). Effect of moderate exercise on the fibrinolytic system in normal young men and women. Brit. med.J., 2, क् 502-506.

Cash, J. D., and Allan, A. G. E. (1967). Effect of mental stress on the $\square$ fibrinolytic reactivity to exercise. Brit. med. J., 2, 545-548.

Dacie, J. V., and Lewis, S. M. (1968). Practical Haematology, 4th ed., p. 72. Churchill, London.

Das, P. C., Allan, A. G. E., Woodfield, D. G., and Cash, J. D. (1967). Fibrin degradation products in sera of normal subjects. Brit. med. J., 4, 718-720.

Diggs, L. W. (1963). Pathology of the spleen. In The Spleen, edited by A. Blaustein, pp. 89-109. McGraw-Hill, New York. 
Diggs, L. W. (1965). Sickle cell crisis. Amer. J. clin. Path., 44, 1-19.

Diggs, L. W. (1973). Anatomic lesions in sickle cell disease. In Sickle Cell Disease: Diagnosis, Management, Education and Research, edited by H. Abramson, J. F. Bertles, and D. L. Wethers. Mosby, St. Louis.

Dodman, B., Cunliffe, W. J., Roberts, B. E., and Buchan, C. W. (1973). Effects of changes in temperature (local and central) on plasma fibrinolytic activity. J. clin. Path., 26, 248-249.

Fearnley, G. R. (1964). Measurement of spontaneous fibrinolytic activity. J. clin. Path., 17, 307-309.

Fearnley, G. R., Balmforth, G., and Fearnley, E. (1957). Evidence of a diurnal fibrinolytic rhythm; with a simple method of measuring natural fibrinolysis. Clin. Sci., 16, 645-650.

Gilles, H. M., Reid, H. A., Odutola, A., Ransome-Kuti, O., Lesi, F., and Ransome-Kuti, S. (1968). Arvin treatment for sicklecell crisis. Lancet, 2, 542-543.

Green, D., Kwaan, H. C., and Ruiz, G. (1970). Impaired fibrinolysis in sickle-cell disease; relation to crisis and infection. Thrombos. Diathes. haemorrh. (Stuttg.), 24, 10-16.

Green, D., and Ruiz, G. (1968). Coagulation abnormalities in sickle cell disease. Proceedings of the Central Society for Clinical Research, Chicago. J. Lab. clin. Med., 72, 877.

Haddock, D. R. W., Bonotey-Ahulu, F. I. D., Janosi, M., AnkraBadu, G., and Reid, H. A. (1973). Thrombosis in sickle cell crisis? Controlled trial of ancrod (Arvin) in young adults. J. trop. Med. Hyg., 76, 274-278.

Hardaway, R. M. (1966). Syndromes of Disseminated Intravascular Coagulation, p. 318. Thomas, Springfield, Illinois.

Hardisty, R. M., and Ingram, G. I.C. (1965). Bleeding Disorders. Investigation and Management, pp. 304-306. Blackwell, Oxford.

Haut, M. J., Cowan, D. H., and Harris, J. W. (1973). Platelet function and survival in sickle cell disease. J. Lab. clin. Med., 82, 44-53.

Hilgartner, M. W., Horowitz, H., Erlandson, M., Ferguson, A., and Smith, C. H. (1961). Studies of the coagulation mechanism in patients with sickle-cell anemia. Amer. J. Dis. Child., 102, 591-592.

Hutchinson, R. M., Merrick, M. V., and White, J. M. (1973). Fat embolism in sickle cell disease. J. clin. Path., 26, 620-622.

Ihenacho, H. N. C., Breeze, G. R., Fletcher, D. J., and Stuart, J. (1973). Consumption coagulopathy in congenital heart-disease. Lancet, 1, 231-234.
Jones, S. R., Binder, R. A., and Donowho, E. M. (1970). Sudden death in sickle-cell trait. New Engl. J. Med., 282, 323-325.

Mahmood, A. (1969). Fibrinolytic activity and sickle cell crises. Brit. med. J., 1, 52-53.

Mahmood, A., Macintosh, D. M., and Shaper, A. G. (1967). Fibrinolytic activity in the clinical crisis of sickle cell anaemia. Brit. med. J., 3, 653-654.

Mann, J. R., Breeze, G. R., Deeble, T. J., and Stuart, J. (1972). Ancrod in sickle-cell crisis. Lancet, 1, 934-937.

Merskey, C., Kleiner, G. J., and Johnson, A. J. (1966). Quantitative estimation of split products of fibrinogen in human serum, relation to diagnosis and treatment. Blood, 28, 1-18.

Murphy, R. C., Jr., and Shapiro, S. (1945). The pathology of sickle cell disease. Ann. intern. Med., 23, 376-397.

Nalbandian, R. M. (1973). Clinical use of urea in sickle cell disease. In Sickle Cell Hemoglobin: Molecule to Man, edited by $\mathbf{M}$. Murayama and R. M. Nalbandian, p. 155. Little, Brown, Boston.

Ratnoff, O. D., and Menzie, C. (1951). A new method for the determination of fibrinogen in small samples of plasma. J. Lab. clin. Med., 37, 316-320.

Remmert, L. F., and Cohen, P. P. (1949). Partial purification and properties of a proteolytic enzyme of human serum. J. biol. Chem., 181, 431-448.

Replogle, R. L., Meiselmann, H. J., and Merrill, E. W. (1967). Clinical implications of blood rheology studies. Circulation, 36, 148-159.

Salvaggio, J. E., Arnold, C. A., and Banov, C. H. (1963). Long-term anticoagulation in sickle-cell disease: a clinical study. New Eng. J. Med., 269, 182-186.

Walsh, R. T., Lusher, J. M., and Barnhart, M. I. (1973). Coagulation and fibrinolysis studies in sickle cell anemia. In Sickle Cell Disease, edited by E. F. Mammen, G. F. Anderson, and M. I. Barnhart, p. 271-279. Schattauer Verlag, Stuttgart.

Walters, J. H. (1958). Vascular occlusion in sickle cell disease. Proc. roy. Soc. Med., 51, 646-648.

Weaver, J. P. A., Evans, A., and Walder, D. N. (1969). The effect of increased fibrinogen content on the viscosity of blood. Clin. Sci., 36, 1-10.

Wells, R. E., Jr., Grawronski, T. H., Cox, P. J., and Perera, R. D. (1964). Influence of fibrinogen on flow properties of erythrocyte suspensions. Amer. J. Physiol., 207, 1035-1040. 